\title{
Rapid Detection of Rifampicin- and Isoniazid-Resistant Mycobacterium tuberculosis Using Real-Time PCR
}

\author{
Leyla Sahebi, ${ }^{1}$ Khalil Ansarin,, ${ }^{1,}$ Amir Monfaredan, ${ }^{2}$ Safar Farajnia, ${ }^{3}$ Seiran Nili, ${ }^{4}$ and Majid Khalili ${ }^{5}$ \\ ${ }^{1} \mathrm{PhD}$ of Molecular Epidemiology, Tuberculosis and Lung Disease Research Center, Tabriz University of Medical Sciences, Tabriz, IR Iran \\ ${ }^{2}$ Department of Hematology, Faculty of Medicine, Tabriz Branch, Islamic Azad University, Tabriz, IR Iran \\ ${ }^{3}$ Drug Applied Research Center, Tabriz University of Medical Sciences, Tabriz, IR Iran \\ ${ }^{4} \mathrm{PhD}$ Student of Epidemiology, Health Deputy, Kurdistan University of Medical Sciences, Sanandaj, IR Iran \\ ${ }^{5}$ Medical Philosophy and History Research Center, Tabriz University of Medical Sciences, Tabriz, IR Iran \\ "Corresponding author: Khalil Ansarin, Tuberculosis and Lung Disease Research Center, Tabriz University of Medical Sciences, Tabriz, IR Iran. Tel/Fax: +98-04113378093, E-mail: \\ sahebileila@yahoo.com
}

Received 2015 April 10; Revised 2015 June 28; Accepted 2015 July 14.

\begin{abstract}
Background: Accurate and rapid detection of drug-resistant Mycobacterium tuberculosis is fundamental for the successful treatment of tuberculosis (TB).

Objectives: The aim of this study was to determine the frequency of common mutations leading to isoniazid (INH) and rifampicin (RMP) resistance.

Patients and Methods: In a cross-sectional study carried out in 2014, 90 patients with M. tuberculosis from five border provinces of Iran were selected. After a full clinical history and physical evaluation, real-time polymerase chain reaction (PCR) technique was performed for the detection of mutations in the patients' katG and rpoB genes. The results were compared with results of a standard proportion method as well as a multiplex allele-specific PCR (MAS-PCR).

Results: A total of 23 mutations were found in isolates among which, codon katG 315, rpoB P1 (511 - 519 sequence) and rpoB P2 (524-533 sequence) were responsible for seven, nine and seven cases, respectively. The mean (standard deviation(SD)) of melting temperature (Tm) in katG 315 codon, rров P1 and $\mathrm{P} 2$ sequences in susceptible and mutant isolates was as follows: $k a t G 85.4^{\circ} \mathrm{C}(0.18)$ and $87.54^{\circ} \mathrm{C}$ (0.62); rpoB P1 $84.6^{\circ} \mathrm{C}(0.61)$ and $82.9^{\circ} \mathrm{C}(0.38) ; r p o B ~ P 283.4^{\circ} \mathrm{C}(0.18)$ and $85.3^{\circ} \mathrm{C}(0.19)$, respectively. In comparison to the standard proportion test, the sensitivity of real-time PCR in detecting INH- and RMP-resistant mutations was $75 \%$ and $83.3 \%$, respectively. In comparison to the MAS-PCR test, $100 \%$ of $k a t G 315$ mutations and $80 \%$ of $r p o B$ mutations were determined. Overall, $10 \%$ of the patients were diagnosed with a recurrence of TB. Age and previous history of TB treatment increased mutation odds in $r p o B$ sequences $(\mathrm{P}=$ $0.046, \mathrm{P}=0.036$, respectively).

Conclusions: Detection of drug resistance associated with mutations through real-time PCR by melting analysis technique showed a high differentiating power. This technique had high concordance with the standard proportion test and MAS-PCR results.
\end{abstract}

Keywords: Drug Resistance, Real-Time PCR, Melt Curve Technique, Mycobacterium tuberculosis

\section{Background}

Tuberculosis (TB), a disease as old as human life, remains a serious worldwide health threat (1). Second-line drugs, which are expensive and toxic, are an inevitable treatment course for Mycobacterium tuberculosis isolates that are resistant to first-line medications. This form of $M$. tuberculosis is known as multidrug-resistant M. tuberculosis (MDR-M. tuberculosis) (2). Immediate and accurate treatment of TB is essential for controlling the disease; therefore, rapid and accurate detection of drug resistance is a key factor in the effort to control MDR-TB (3). The proportion method is a standard drug-susceptibility test for detection of drug resistance in M. tuberculosis (4). However, this test demands from eight days to more than one month for completion, a long time for a patient who is likely subjected to suboptimal treatment. Moreover, in most developing countries like Iran, drug-susceptibility tests are available only in reference laboratories, and because of this low availability, results are delayed (5).

According to broad analyses, mutations in the rpoB gene at the $81 \mathrm{bp}$ region are the cause of more than $98 \%$ of rifampicin (RMP) resistance (6), and a change in the katG 315 codon is the cause of more than 50\% of isoniazid (INH) resistance (7). The world health organization (WHO) recommends the development and implementation of molecular approaches for detecting M. tuberculosis drug-susceptibility, especially in developing countries (5). Real-time polymerase chain reaction (PCR) is a widely used 
molecular technique, as it is a high-speed method with a low risk of contamination (8-10). Melting curve analysis is a simple approach for detecting mutations by real-time PCR (1).

\section{Objectives}

The purpose of this study was to assess the potential of real-time PCR melting curve analysis for the detection of mutations associated with INH and RMP resistance in $M$. tuberculosis clinical isolates.

\section{Patients and Methods}

In a cross-sectional study, 90 patients with pulmonary TB were randomly selected for analysis in 2014 from five border provinces of Iran, including east and west Azerbaijan, Ardebil, Kermanshah and Kurdistan. The university ethics committee code of study was 1391/6/18/5/4/5375.

\subsection{Demographic Data and Analysis}

Demographic and environmental data were collected using a questionnaire. Clinical characteristics were provided using the information mentioned in the surveying of medical records and with the assistance of the physician in charge of the treatment of TB; additional clinical details were obtained from personal interviews and home inspections. The validity and reliability of the questionnaire had been previously confirmed through a pilot study (Cronbach's alpha $=0.98$ ). Data was analyzed using univariate logistic regression in SPSS 18 (233 south Wacker drive, 11th floor, Chicago, Illinois, USA). The validity (sensitivity and specificity) test was done using the OpenEpi online program (open source epidemiologic statistics for public health, version. www.OpenEpi.com).

\subsection{Inclusion Criteria}

As determined by ELISA (enzyme-linked immune sorbent assay) test, all patients were HIV negative and received DOTS (directly observed therapy, short-course). The inclusion criteria of the study were smear-positive pulmonary TB with at least two initially positive sputum smears for acid-fast bacilli, or one positive sputum smear and radiographic abnormalities consistent with active pulmonary $\mathrm{TB}$, or one positive smear and positive culture for $M$. tuberculosis (11). The M. tuberculosis complex was identified by culturing on Lowenstein-Jensen (LJ) medium containing pnitro benzoic acid. The $M$. tuberculosis species was identified based on a niacin test and a nitratase test (a positive reaction of a pink color indicated nitrate had been reduced to nitrite (12).

\subsection{Standard Proportion Test}

A drug-susceptibility test was carried out in LJ medium according to the proportion method recommended by WHO/IUTLD (11) using INH: 0.2 mg/L, RMP: 40 mg/L. Incubation of the samples was continued for 43 days.

\subsection{DNA Extraction}

DNA was extracted from clinical isolates grown on $\mathrm{LJ}$ medium in the following process: at least two to three $M$. tuberculosis colony loops were suspended in $1 \mathrm{X}$ TE buffer, inactivated at $80^{\circ} \mathrm{C}$ for 20 minutes, washed three times with $1 \mathrm{X} \mathrm{TE}$, and incubated with lysozyme at $37^{\circ} \mathrm{C}$ for 24 hours. Afterward, proteinase $\mathrm{K}$ was added, and the samples were incubated at $65^{\circ} \mathrm{C}$ for another 24 hours. After adding $\mathrm{CTAB} / \mathrm{NaCl}+5 \mathrm{M} \mathrm{NaCl}$ and chloroform/isoamyl alcohol, isopropanol was added to each sample and maintained in a $-20^{\circ} \mathrm{C}$ freezer for 24 hours. Finally, after washing the DNA with $70 \%$ ethanol, the DNA was dissolved in $30 \mu \mathrm{L}$ of distilled water and preserved at $-20^{\circ} \mathrm{C}$ until use (13).

\subsection{Real-Time PCR}

Three dually labeled probes and four primers were designed to detect two genes associated with drug resistance. Usually, more than four probes should be used to assess the 81 bp region of the $r p o B$ gene $(1,2,14)$. We designed two long probes to detect mutations at $r p o B$ for decreasing workload and consuming costs. The sequence of primers (forward and in reverse) and probes in rpoB 511 to 519 and 524 to 533 codons, and 315 codons $k a t G$ genes are described in Table 1(1).

Table 1. The Sequence of Primers and Probes in rpoB and katG Codons (1)

\begin{tabular}{|c|c|c|c|}
\hline $\begin{array}{l}\text { Detection } \\
\text { Target }\end{array}$ & Probes (5'-3') & $\begin{array}{l}\text { Forward } \\
\text { Primers (5'-3') }\end{array}$ & $\begin{array}{l}\text { Reverse } \\
\text { Primers (5'-3') }\end{array}$ \\
\hline katG 315 & $\begin{array}{l}\text { TCA CCA GCG } \\
\text { GCA TCG }\end{array}$ & $\begin{array}{l}\text { CGT ATG GCA } \\
\text { CCG GAA CCG } \\
\text { GTAA }\end{array}$ & $\begin{array}{l}\text { GCT CCC ACT } \\
\text { CGT AGC CCG } \\
\text { TAC A }\end{array}$ \\
\hline гров 511-519 & $\begin{array}{l}\text { GGT TGT GGT } \\
\text { CCA GAA TTG } \\
\text { GCT CAG C }\end{array}$ & $\begin{array}{l}\text { GCC GCG ATC } \\
\text { AAG GAG TTC } \\
\text { TTC }\end{array}$ & $\begin{array}{l}\text { CGG CAC GCT } \\
\text { CAC GTG ACA } \\
\text { GAC }\end{array}$ \\
\hline гроB 524-533 & $\begin{array}{l}\text { GCC CCA GCG } \\
\text { TCG ACA GCG } \\
\text { GTG CTT GTC GG }\end{array}$ & & \\
\hline
\end{tabular}

The content of real-time PCR reaction in a thermal cycler (applied biosystems® thermal cyclers CA, USA) with a total volume of $20 \mu \mathrm{L}$ was as follows: PCR master mix (premix Ex Taq, Takara Bio Inc., Japan): $10 \mu \mathrm{L}$, primer mix (Forward-Reverse): $0.25 \mu \mathrm{L}$, probe: $0.5 \mu \mathrm{L}$, Rox reference Dye (Takara Bio Inc., Japan): $1 \mu \mathrm{L}$, sterilized distilled water: 
7.25 $\mu \mathrm{L}$ and extracted DNA with the maximum concentration of $100 \mathrm{ng}: 1 \mu \mathrm{L}$. PCR conditions were as follows: primary denaturation at $95^{\circ} \mathrm{C}$ for 10 minutes followed by denaturation at $95^{\circ} \mathrm{C}, 10$; annealing at $58^{\circ} \mathrm{C}$ for 30 seconds and extending $72^{\circ} \mathrm{C}$ for 15 seconds ( 40 cycle). Each probe had a different melting condition in PCR so that, for rpoB 511 to 519: $95^{\circ} \mathrm{C}$ at 15 seconds; $58^{\circ} \mathrm{C}$ at 15 seconds; $95^{\circ} \mathrm{C}$ at 15 . For rpoB 524 to $533: 95^{\circ} \mathrm{C}$ at $15 ; 58^{\circ} \mathrm{C}$ at $15 ; 95^{\circ} \mathrm{C}$ at 15 and melt katG 315: $95^{\circ} \mathrm{C}$ at 15 seconds; $55^{\circ} \mathrm{C}$ at 15 seconds; $95^{\circ} \mathrm{C}$ at 15 seconds. The isolates with a melting temperature ( $\mathrm{Tm})$ difference of $1.5^{\circ} \mathrm{C}$ (compared to the Tm of sensitive isolates) were considered as mutant isolates $(1,2,14)$.

\subsection{Multiplex Allele-Specific PCR (MAS-PCR)}

Using the MAS-PCR technique, codon 315 of the katG gene and codons 516, 526 and 531 of the rpoB gene were evaluated. Four allele-specific primers corresponding to the four target codons and two common primers were used in the MAS-PCR assay as described by Yang et al. (15). The MAS-PCR reaction was prepared in a $25 \mu \mathrm{L}$ volume and contained $1 \mu \mathrm{L}$ primer mix (6 primers: rpoB 516, rрoB 526, rрoB 531, RRm, katG FC, katG RC), $10 \mu \mathrm{L}$ master mix (Ampliqon, Denmark), $1 \mu \mathrm{L}$ DNA (with a concentration of at least 100 $\mathrm{ng} / \mu \mathrm{L}$ ) and $13 \mu \mathrm{L}$ of distilled water. The thermal cycler (PeQ lab, primus 96 , Germany) conditions followed were: initial denaturizing at $94^{\circ} \mathrm{C}$ for 7 minutes, 35 cycles of $94^{\circ} \mathrm{C}$ for 30 seconds, $68^{\circ} \mathrm{C}$ for 40 seconds and a final extension at $72^{\circ} \mathrm{C}$ for 5 minutes (Figure 1 ).

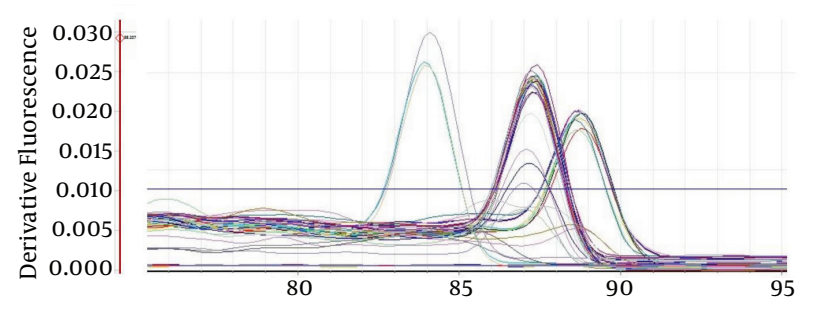

Figure 1. Melting Temperature Curve Analysis for 46 MTB Patients by katG315

\section{Results}

\subsection{Descriptive Results}

The studied isolates were collected from 90 patients with an average age of 54.35 years (ranging from 15 - 83); 44 cases ( $48.9 \%$ ) were male and 46 cases (51.1\%) female. The content of sampling in different provinces was as follows: 28 cases (31.1\%) were from east Azerbaijan, 25 cases (27.8\%) from West Azerbaijan, 9 cases (10\%) from Ardebil, 16 cases (17.8\%) from Kermanshah and 12 cases (13.3\%) from Kurdistan. TB category II or patients who are either diagnosed with a previous infection of TB or who have received the first line drugs but have faced failure, relapse or drug resistance during the treatment, had a shortage of access to drugs, or have encountered faults in receiving the treatment plan from health care providers, was detected in 9 (10\%) patients. Seventy-seven percent of patients in category II had mutations in their $k a t G$ and $r p o B$ genes.

\subsection{Real-Time PCR Results}

Melting curve method was used to study mutations associated with drug resistance. The mutations were detected by comparing the Tm of amplicons of resistant isolates with that of susceptible isolates. The frequency of all mutations was 23, where the frequency of mutations was nine for $r p o B$ P1, 7 for $r p o B$ P2 and 7 for katG 315. The frequency of isolates with at least one mutation in $r p o B$ or $k a t G$ was 11 cases. The frequency of mutations at kat 315 and rpoB P1 or rpoB P2 (in the likelihood of MDR-TB) was three cases (Figure 2). The average Tm and standard deviation (SD) of susceptible isolates was as follows: $315 \mathrm{katG}$ codon 85.4, 0.18; rpoB P1 sequence 84.6, 0.6 and rpoB P2 sequence $83.4,0.18$ (Table 2)

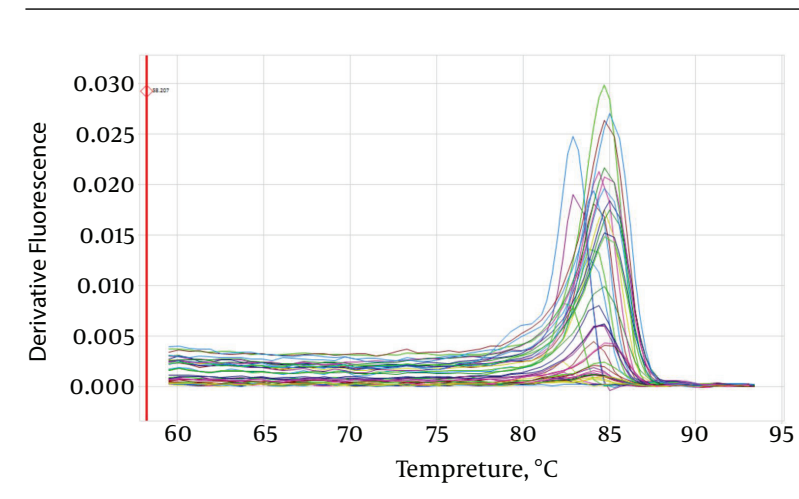

Figure 2. Melting Temperature Curve Analysis for $46 \mathrm{M}$. tuberculosis Patients by $r p o B$ P1

Table 2. Melt Temperature Results in katG 315, rрoв P1 and rpoB P2 Sequences

\begin{tabular}{lccc}
\hline Type Mutation & $\begin{array}{c}\text { TM, }{ }^{\circ} \mathrm{C}(\mathrm{SD}) \\
\text { Susceptible } \\
\text { Isolates }\end{array}$ & $\begin{array}{c}\text { TM, }{ }^{\circ} \mathrm{C}(\mathrm{SD}) \\
\text { Mutant } \\
\text { Isolates }\end{array}$ & $\begin{array}{c}\text { Mean } \\
\text { Difference, }{ }^{\circ} \mathrm{C}\end{array}$ \\
\hline katG 315 & $85.4(0.18)$ & $87.54(0.62)$ & 2.14 \\
rpoB P1 & $84.6(0.61)$ & $82.9(0.38)$ & -1.7 \\
\hline rpoB P2 & $83.37(0.18)$ & $85.27(0.19)$ & 1.9 \\
\hline
\end{tabular}

The average Tm of $r p o B$ P1 in mutant isolates was 82.9 (SD: 0.38). In other words, mutant isolates in rpoB 511 to 519 codons were accompanied by a Tm decrease of $1.7^{\circ} \mathrm{C}$ (Table 
2). The Tm of $r p o B$ P2 in mutant isolates was 85.3 (SD: 0.19). This implies that mutations in rpoB 524 to 533 codons were accompanied by a $\mathrm{Tm}$ increase $\left(1.9^{\circ} \mathrm{C}\right)$. Therefore, a difference of more than two standard deviations from the rpoB P1 Tm and a difference of 10 standard deviations from the rров P2 Tm significantly accompanies mutation isolates. The average $\mathrm{Tm}$ in katG 315 in mutant isolates was $87.54^{\circ} \mathrm{C}$ (SD: 0.62) which was increased by $2.1^{\circ} \mathrm{C}$ compared with 315 $k a t G \mathrm{Tm}$ in susceptible isolates (Table 2 ). It should be noted that three isolates displayed a $3.42^{\circ} \mathrm{C}$ decrease in the $k a t G$ $\mathrm{Tm}$, and were removed from analysis (Figure 2). The distribution of frequency of katG and rpoB mutations based on provinces is shown in Table 3.

Table 3. Frequency of Mutations in katG and rров Codons Based on Various Provinces ${ }^{\mathrm{a}, \mathrm{b}}$

\begin{tabular}{lccc}
\hline $\begin{array}{l}\text { Provinces } \\
\text { (Number) }\end{array}$ & $\begin{array}{c}\text { Frequency of } \\
\text { katG Mutation }\end{array}$ & $\begin{array}{c}\text { Frequency of } \\
\text { rpoB Mutation }\end{array}$ & $\begin{array}{c}\text { Frequency of } \\
\text { Both katG and } \\
\text { rpoB Mutation }\end{array}$ \\
\hline $\begin{array}{l}\text { East } \\
\text { Azerbaijan } \\
(\mathbf{2 8}) \mathbf{b}\end{array}$ & $1(4.0)$ & $4(14.3)$ & $1(4.0)$ \\
\hline $\begin{array}{l}\text { West } \\
\text { Azerbaijan(25) }\end{array}$ & $1(4.0)$ & $4(16.0)$ & $0(0.0)$ \\
\hline Ardabil(9) & $3(33.3)$ & $1(11.1)$ & $1(11.1)$ \\
\hline $\begin{array}{l}\text { Kermanshah } \\
(\mathbf{1 6})\end{array}$ & $1(6.25)$ & $4(25.0)$ & $0(0)$ \\
\hline Kurdistan(12) & $3(25.0)$ & $1(8.3)$ & $1(8.3)$ \\
\hline Total (90) & $9(8.0)$ & $14(15.6)$ & $3(3.3)$ \\
\hline
\end{tabular}

${ }^{\mathrm{a}}$ Value are expressed as No. (\%)

$\mathrm{b}_{3}$ of 28 isolates were removed from $k a t G$ mutation analysis.

4.3. Comparison of Real-Time PCR Results and Standard Proportion Test

In this study, eight and 12 cases had resistance to INH and RMP, respectively. However, 4.4\% (four cases) were MDR, i.e., they showed resistance to both INH and RMP. The sensitivity and specificity of real-time PCR in the detection of INH resistance were 75\% (CI 95\%; 40.93, 92.85) and 97.47\%, respectively (CI 95\%; 91.23, 99.3); in the detection of RMP resistance, its sensitivity and specificity were 83.3\% (CI 95\%; 55.2, 95.3) and 98.72\% (CI 95\%; 93.09, 99.77) (Table 4).

\subsection{Comparison of Real-Time PCR Results With MAS-PCR}

The sensitivity and specificity of real-time PCR technique in identifying katG mutation by MAS- PCR were 100.0\% (CI 95\%; 51.0, 100.0) and 95.18\% (CI 95\%; 88.25, 98.11), respectively; in detection of mutation in rpoB codons (516, 526 and 531) its sensitivity and specificity were $80.0 \%$ (CI 95\%; 49.02, 94.33) and 96.25\% (CI 95\%; 89.55, 98.72), respectively (Table 5).
Studies of the relationship between age and mutation odds in the rроB gene revealed a significant statistical relationship $(\beta=0.85$ and $\mathrm{P}=0.046)$. It was observed, however, that a previous history of using TB drugs increased mutation odds at $\operatorname{rpoB}(\mathrm{OR}=16$ and $\mathrm{P}=0.036)$ while gender, household size number, immigration history and smoking did not $(\mathrm{P}>0.005)$. There was also no significant relationship between the above-mentioned variables and mutation odds in katG 315 (P > 0.005).

\section{Discussion}

The global incidence of TB drug resistance is very high in TB patients with a recurring illness. The recurrence rate in low- and middle-income countries is estimated to be approximately $10-20 \%$ (16). In 2004 , approximately $6.8 \%$ of the TB patients in Iran were in the recurrent group (17). We found that $7.2 \%$ of the patients in our previous study had recurrent $\mathrm{TB}$ (17). In the present study, $10 \%$ of patients were diagnosed with recurrent TB. The higher frequency of mutations (25\%) in the present study might be due to a higher proportion of recurrent TB in isolates in this study (10\%).

Mohajeri et al. (2015) used a density array (LCD-array) to detect mutations within the 90-bp rpoB region in the sputum of TB patients from western Iran. Of the $125 \mathrm{M}$. tuberculosis isolates, 35 subjects (28\%) were found to be rifampicin resistant (18). This result had c very close to consistent with our study (25\%).

In this study, we performed an inexpensive and rapid test using a real-time PCR approach, employing melting curve analysis of dually labeled probes in order to detect current mutations leading to INH and RMP resistance. A number of similar studies have used melting curve analysis based on FRET (fluorescence resonance energy transfer) probes to detect current mutations in $\mathrm{TB}(1,10,14,15)$. In our current study, the maximum mean SD of Tm in susceptible isolates was $0.61^{\circ} \mathrm{C}$. On the other hand, the minimum distance between $\mathrm{Tm}$ in susceptible isolates and mutant isolates was above $1.7^{\circ} \mathrm{C}$ (related to rpoB). This implies that the detection of mutations using the melting analysis technique provided a higher differentiating ability. In some previous studies $(8,14,19)$, Tm of katG and rpoB in mutant isolates differed more than two standard deviations from the average Tm of susceptible species. Torres et al. (19) studied 30 RMP-resistant isolates using two pairs of primers. They showed a decrease by $6^{\circ} \mathrm{C}$ in Tm of mutant isolates in rpoB 513 to 516 codons, but an increase by $2^{\circ} \mathrm{C}$ in Tm of mutant isolates in $r p o B 526$ to 531 codons (19). In Garcia de Viedma et al. study (20), the isolates with mutation in $r p o B 515$ and 516 codons showed a decrease of 2.48 . $8.39^{\circ} \mathrm{C}$ in $\mathrm{Tm}$, while codons 526 and 531 showed a decrease of $6.92^{\circ} \mathrm{C}$, which is inconsistent with our results. 
Table 4. Diagnostic of INH and RMP Resistance Test Evaluation of MTB Tuberculosis Patients in Real-Time PCR Results

\begin{tabular}{|c|c|c|c|c|}
\hline \multirow{2}{*}{$\begin{array}{l}\text { Real Time-PCR Test } \\
\text { katG }\end{array}$} & \multicolumn{2}{|c|}{ Proportion Test } & \multirow{2}{*}{$\begin{array}{c}\text { Sensitivity (CI 95\%) } \\
75 \%(40.93,92.85)\end{array}$} & \multirow{2}{*}{$\begin{array}{c}\text { Specificity (CI 95\%) } \\
97.47 \%(91.23,99.3)\end{array}$} \\
\hline & Resistance to INH & Sensitive to INH & & \\
\hline katG 315 mutation & 6 & 2 & & \\
\hline Without mutation in katG 315 & 2 & 77 & & \\
\hline гров & Resistance to RMP & Sensitive to RMP & $83.3 \%(55.29,95.3)$ & $98.72 \%(93.72,99.77)$ \\
\hline rpoB codons( $\mathrm{P} 1$ and $\mathrm{P} 2)$ mutation & 10 & 1 & & \\
\hline Without mutation in rpoB codons ( $\mathrm{P} 1$ and $\mathrm{P} 2$ ) & 2 & 77 & & \\
\hline
\end{tabular}

Table 5. Diagnostic of katG 315 and rpoB (codons 516, 526 and 531) Mutation Test Based MAS-PCR Evaluation of MTB Tuberculosis Patients in Real-Time PCR Results

\begin{tabular}{|c|c|c|c|c|c|}
\hline \multirow{2}{*}{\multicolumn{2}{|c|}{$\begin{array}{l}\text { Real Time-PCR Test } \\
\text { katG }\end{array}$}} & \multicolumn{2}{|c|}{ MAS-PCR Test } & \multirow{2}{*}{$\begin{array}{c}\text { Sensitivity (CI 95\%) } \\
100 \%(51.01,100)\end{array}$} & \multirow{2}{*}{$\begin{array}{c}\text { Specificity (CI 95\%) } \\
95.18 \%(88.25,98.11)\end{array}$} \\
\hline & & KatG 315 mutation & Without mutation in KatG 315 & & \\
\hline & katG 315 mutation & 4 & 4 & & \\
\hline & Without mutation in katG 315 & 0 & 79 & & \\
\hline \multirow[t]{3}{*}{ гров } & & $\begin{array}{l}\text { mutation in } r p o B(516,526 \text { and } 531) \\
\text { codons }\end{array}$ & $\begin{array}{l}\text { Without mutation in rpoB }(516,526 \\
\text { and 531) codons }\end{array}$ & $80.0 \%(49.02,94.33)$ & $96.25 \%(89.55,98.72)$ \\
\hline & $\begin{array}{l}\text { rpoB codons ( } \mathrm{P} 1 \text { and } \mathrm{P} 2) \\
\text { mutation }\end{array}$ & 8 & 3 & & \\
\hline & $\begin{array}{l}\text { Without mutation in } r p o B \\
\text { codons ( } \mathrm{P} 1 \text { and } \mathrm{P} 2)\end{array}$ & 2 & 77 & & \\
\hline
\end{tabular}

Torres et al. showed that the average Tm of katG 315 in susceptible species was $72.8^{\circ} \mathrm{C}(19)$. Also, Marin et al. estimated an average of $70.85^{\circ} \mathrm{C}$ of $\mathrm{Tm}$ in the $315 \mathrm{katG}$ codon in susceptible species (14). According to our study's estimations, the average Tm of katG of mutated species was $87.54^{\circ} \mathrm{C}$. In our current study, $83.3 \%$ of RMP-resistant isolates were detected by real-time PCR technique using two probes that included codons 513 to 516 and codons 526 to 531. However, $75 \%$ of INH-resistant isolates were detected by this technique. It should be noted that the result of the real-time PCR test was blind to the proportional test result.

In this study, $80.0 \%$ of rpoB codon mutations in MASPCR were detected by real-time PCR technique using two probes including codons 513 to 516 and codons 526 to 531. However, $100 \%$ of katG mutations were detected by this technique. In the study by Feizabadi et al. (2009 - 2012) on M. tuberculosis clinical isolates, the sensitivity and specificity of RMP resistance detection by high-resolution melting curve (HRM) analysis of the 129-bp fragment of $r p o B$ were estimated at $95 \%$ and $100 \%$, respectively. Also, sensitivity and specificity of INH resistance detection by HRM analysis were reported at $85.7 \%$ and $100 \%$, respectively (21).

Sheikholslami et al. (2011) calculated the validity of single-strand confirmation polymorphism to detect drug resistance compared to DNA sequencing. The sensitivity and specificity of this assay in detection of the rpoB gene were $70.8 \%$ and $88 \%$, respectively (22). It is clear from our research that, previous history of TB treatment and aging increased the odds of RMP resistance. A great number of studies, however, have found a significant relationship between previous history of TB treatment and drug resistance $(20,23,24)$, while there are contradictory findings regarding the relationship between age and mutation odds $(20,23)$. The limitation of this study was its low budget, so it was not possible to perform the study on a higher sample size. Also, the role of mutation of inhA, ahp and oxyR genes in the creation of INH resistance was not identified.

In conclusion, the detection of drug-resistant mutations through melting analysis technique had a high differentiating ability. It is essential to monitor older patients and those with a previous history of TB treatment using rapid and accurate techniques tof determining their drug resistance odds.

\section{Acknowledgments}

The authors thank the following persons and institutions: the staff of the east Azerbaijan reference laboratory, TB and lung disease research center and province health center. At Tabriz University of Medical Sciences: Maryam Seyyedi, BSC of lab sciences; Dr. Seyyed Reza Moaddab, Ph.D. microbiologist; Jalil Rashedi, MS.c of microbiology; 
Ahad Zarei, BSC of lab sciences; Hasan Yekrang, Ms.c of health service management; Dr. Simin Khayyat Zadeh, MD. At workers of west Azerbaijan laboratory and province health center: Dr. Tavana, MD; Dr. Nemati, MD; Mr. Seyyedi and Sarhangi, BSC of lab sciences. Workers of Ardabil laboratory and province health center: Dr. Arezu Moini, MD, and Mrs. Saraii, BSC of lab sciences. Workers of the Kermanshah reference laboratory: Sara Atashi, BSC of lab sciences; Parviz Mohajeri, microbiologist; Kamalledin Jadidian, M.Sc. of microbiology. Workers of Kurdistan laboratory and province health center: Mr. Galilini, BSC of lab sciences, and Lesley Carson, for editorial assistance.

\section{Footnote}

Authors' Contribution: Leyla Sahebi and Khalil Ansarin researched and wrote the study design; Leyla Sahebi collected data; Seiran Nili and Majid Khalili helped collect the data; Leyla Sahebi and Amir Monfaredan performed the study design; Leyla Sahebi, Amir Monfaredan and Khalil Ansarin interpreted the data; Leyla Sahebi and Safar Farajnia wrote the manuscript all authors read and approved the final manuscript.

\section{References}

1. Luo T, Jiang L, Sun W, Fu G, Mei J, Gao Q. Multiplex Real-Time PCR Melting Curve Assay To Detect Drug-Resistant Mutations of Mycobacterium tuberculosis. J Clin Microbiol. 2011;49(9):3132-8. doi: 10.1128/jcm.02046-10.

2. Kocagoz T, Saribas Z, Alp A. Rapid Determination of Rifampin Resistance in Clinical Isolates of Mycobacterium tuberculosis by Real-Time PCR.J. Clin Microbiol. 2005;43(12):6015-619. doi:10.1128/jcm.43.12.60156019.2005.

3. Velayati AA, Masjedi MR, Farnia P, Tabarsi P, Ghanavi J, ZiaZarifi AH, et al. Emergence of New Forms of Totally Drug-Resistant Tuberculosis Bacilli. Chest. 2009;136(2):420-5. doi:10.1378/chest.08-2427.

4. Ardito F, Posteraro B, Sanguinetti M, Zanetti S, Fadda G. Evaluation of BACTEC Mycobacteria Growth Indicator Tube (MGIT 960) Automated System for Drug Susceptibility Testing of Mycobacterium tuberculosis. Journal of Clinical Microbiology. 2001;39(12):4440-4. doi: 10.1128/jcm.39.12.4440-4444.2001.

5. Sekiguchi JI, Miyoshi-Akiyama T, Augustynowicz-Kopec E, Zwolska Z, Kirikae F, Toyota E, et al. Detection of Multidrug Resistance in Mycobacterium tuberculosis. J Clin Microbiol. 2006;45(1):179-92. doi: 10.1128/jcm.00750-06.

6. Riska PF, Jacobs J, Alland D. Molecular determinants of drug resistance in tuberculosis. Int J Tuberc Lung Dis. 2000;4(2 Suppl 1):S4-10. [PubMed:10688142].

7. Park WG, Bishai WR, Chaisson RE, Dorman SE. Performance of the Microscopic Observation Drug Susceptibility Assay in Drug Susceptibility Testing for Mycobacterium tuberculosis. J Clin Microbiol. 2002;40(12):4750-2. doi:10.1128/jcm.40.12.4750-4752.2002.

8. Lin SYG, Probert W, Lo M, Desmond E. Rapid Detection of Isoniazid and Rifampin Resistance Mutations in Mycobacterium tuberculosis Complex from Cultures or Smear-Positive Sputa by Use of Molecular Beacons. J Clin Microbiol. 2004;42(9):4204-8. doi: 10.1128/jcm.42.9.42044208.2004 .
9. Helb D, Jones M, Story E, Boehme C, Wallace E, Ho K, et al. Rapid Detection ofMycobacterium tuberculosisand Rifampin Resistance by Use of On-Demand, Near-Patient Technology. J Clin Microbiol. 2010;48(1):229-37. doi:10.1128/jcm.01463-09.

10. Garcia de Viedma D, del Sol Diaz Infantes M, Lasala F, Chaves F, Alcala L, Bouza E. New Real-Time PCR Able To Detect in a Single Tube Multiple Rifampin Resistance Mutations and High-Level Isoniazid Resistance Mutations in Mycobacterium tuberculosis. J Clin Microbiol. 2002;40(3):988-95. doi: 10.1128/jcm.40.3.988-995.2002.

11. World Health Organization. Anti-tuberculosis drug resistance in the world: third global report. 2004

12. Rafi A, Moaddab SR. Subspecies tests in: Principles of mycobacteriology. Tabriz: Sotodeh publisher; 2004. pp. 95-114.

13. van Soolingen D, Qian L, de Haas PE, Douglas JT, Traore H, Portaels F, et al. Predominance of a single genotype of Mycobacterium tuberculosis in countries of east Asia. J Clin Microbiol. 1995;33(12):3234-8. [PubMed: 8586708].

14. Marin M, de Viedma DG, Ruiz-Serrano MJ, Bouza E. Rapid Direct Detection of Multiple Rifampin and Isoniazid Resistance Mutations in Mycobacterium tuberculosis in Respiratory Samples by Real-Time PCR. Antimicrob Agents Chemother. 2004;48(11):4293. doi: 10.1128/aac.48.11.4293-4300.2004.

15. Yang Z, Durmaz R, Yang D, Gunal S, Zhang L, Foxman B, et al. Simultaneous detection of isoniazid, rifampin, and ethambutol resistance of Mycobacterium tuberculosis by a single multiplex allelespecific polymerase chain reaction (PCR) assay. Diagn Microbiol Infect Dis. 2005;53(3):201-8. doi:10.1016/j.diagmicrobio.2005.06.007.

16. Dooley KE, Lahlou O, Ghali I, Knudsen J, Elmessaoudi MD, Cherkaoui I, et al. Risk factors for tuberculosis treatment failure, default, or relapse and outcomes of retreatment in Morocco. BMC Public Health. 2011;11(1):140. doi: 10.1186/1471-2458-11-140.

17. Sahebi L, Ansarin K, Maryam S, Monfaredan A, Sabbgh Jadid H. The factors associated with tuberculosis recurrence in the northwest and west of iran. Malays J Med Sci. 2014;21(6):27-35. [PubMed: 25897280].

18. Mohajeri P, Sadri H, Farahani A, Norozi B, Atashi S. Frequency of Mutations Associated with Rifampicin Resistance inMycobacterium tuberculosisStrains Isolated from Patients in West of Iran. Microb Drug Resis. 2015;21(3):315-9. doi:10.1089/mdr.2014.0075.

19. Torres MJ, Criado A, Palomares JC, Aznar J. Use of real-time PCR and fluorimetry for rapid detection of rifampin and isoniazid resistanceassociated mutations in Mycobacterium tuberculosis.J Clin Microbiol. 2000;38(9):3194-9. [PubMed: 10970356].

20. Garcia de Viedma D. Rapid detection of resistance in Mycobacterium tuberculosis: a review discussing molecular approaches. Iran J Clin Infect Disease. 2003;9(5):349-59. doi: 10.1046/j.1469-0691.2003.00695.x.

21. Feizabadi MM, Haeili M, Fooladi AI, Bostanabad SZ, Sarokhalil DD, Siavoshi F. Rapid screening of rpoB and katG mutations in Mycobacterium tuberculosis isolates by high-resolution melting curve analysis. Indian Journal of Medical Microbiology. 2014;32(4):398. doi: 10.4103/0255-0857.142245.

22. Sheikholslami MF, Farnia P, Tabarsi P, Merza MA, Amiri MVP, Mohammadi F, et al. Comparison of polymerase chain reaction single-strand conformation polymorphism with DNA sequencing to detect drug resistance of mycobacterium tuberculosis isolates. Iran J Clin Infect Disease. 2011;6(2):66-70.

23. Weis SE, Slocum PC, Blais FX, King B, Nunn M, Matney GB, et al. The effect of directly observed therapy on the rates of drug resistance and relapse in tuberculosis. N Engl J Med. 1994;330(17):1179-84. doi: 10.1056/NEJM199404283301702. [PubMed: 8139628].

24. Johnson R. Understanding the mechanisms of drug resistance in enhancing rapid molecular detection of drug resistance in Mycobacterium tuberculosis. Stellenbosch University; 2007. 